\title{
Corporate Governance in the Organization for Economic Cooperation and Development (OECD) and Its Influence on the Code of Good Corporate Governance for Peruvian Corporations
}

\author{
Edison Paul Tabra Ochoa \\ Pontifical Catholic University of Peru
}

\begin{abstract}
This paper compares the recent recommendations published by the OECD in 2015 with the recommendations of the Code of Good Corporate Governance for Peruvian Corporations published in 2013. For the author, the Peruvian Code requires the incorporation of several norms that the international organization included in its recent 2015 version in order to prevent future financial crises and promote a greater participation of the shareholder-investor in the governance of the company.
\end{abstract}

Keywords: corporate governance, shareholder, activism, corporation, stakeholder, board of directors

\section{INTRODUCTION}

The practice of corporate governance in Peru is a priority for companies seeking to increase their levels of transparency, certainty and trust. In Peru, the Good Corporate Governance Code for Peruvian Corporations $^{1}$ (2013) has become a mechanism for promoting self-regulation norms that many companies are incorporating in their own codes of conduct to improve their internationalization processes and attract new investors. Many of the recommendations proposed in the Code come from the Organisation for Economic Cooperation and Development (OECD) $)^{2}$, which was published in 2004 and has had an enormous impact on the country.

In 2015, the effects of the financial crisis and the increase in cross-border corporate ownership led the OECD to modify its recommendations to strengthen the protection of the rights of investors and other stakeholders. Currently, these changes are in the implementation stage in the organization's member countries. For this reason, the purpose of this paper is to highlight the recent and significant changes in the OECD proposals, and to propose their incorporation into the current Code of Good Corporate Governance for Peruvian Corporations ${ }^{3}$.

\section{PREVIOUS IDEA OF CORPORATE GOVERNANCE}

The importance of corporate governance in the commercial world is increasingly influential. It arose from the need to protect the interests of investors (shareholders) against the opportunism of the administrator (director and manager) present in those companies where the separation between ownership and management is paramount.

The reason lies in the fact that its understanding does not focus on a knowledge of the legal field but requires the mastery of four perspectives that, along with the legal perspective, make it possible to 
understand its nature and complexity. The first perspective is the economic one that proposes the understanding of corporate governance as a means of reducing agency problems in order to protect the interests of the investor (shareholder) against the opportunism of the agent (executive). According to this perspective, the law becomes an enabling instrument to protect the interests of the owner of the company (shareholder) and, by extension, the stakeholder.

The second place is the ethical perspective that involves the problem of the exercise of corporate values in a company with the aim of preventing business frauds that have as their origin the opportunism of the manager. Thus, directors and senior management must practice a set of principles and virtues in corporate governance in order to satisfy the interests of the organization and set their own standards of behavior in their organization to reduce agency problems.

In turn, the perspective of management in corporate governance is advisory. The management of any company should include rules of governance capable of reducing any economic and financial risk that may affect the interests of the company and its members. In this line of rationale, good corporate governance consists of the management of the company by the director in accordance with his fiduciary duties and accountable for his actions to the owners (shareholders).

Finally, the influence of social responsibility on corporate governance today is evident. The inclusion of the need to incorporate aspects related to the protection of the environment, fundamental rights and governance is important to ensure the long term and the generation of value in any company. Likewise, the figure of the stakeholder (investor, employee, client, government and civil society) is incorporated as the target public for whom the manager must carry out his work diligently and to whom he must be accountable for his work.

\section{CORPORATE GOVERNANCE IN THE OECD}

The OECD is one of the main international organizations that recommended the practice of corporate governance, in the face of the Asian crisis of the nineties, to promote the strengthening of transparency and market confidence towards companies. For this institution, corporate governance practices should promote the economic performance of the company, guarantee the investment return of the company and its shareholders, promote its long-term growth, limit the abuse of power in the use of its resources, adequately supervise the conduct of its managers, protect its investors and reduce the risk of expropriation of its assets ${ }^{4}$.

The 2004 OECD Corporate Governance Principles were developed based on the principles it prepared in 1999 and prompted several changes to their content. As a result of these, the principles were grouped as follows:

I. To ensure the basis for an effective framework for corporate governance.

II. The rights and obligations of shareholders as owners of the company.

III. Equal treatment of shareholders.

IV. The role of stakeholders in Corporate Governance.

V. Disclosure and transparency.

VI. Responsibilities of the Board

Subsequently, the financial crisis of 2008 made clear the need to implement new changes and in 2015 a new version of the principles was published under the name "G20/OECD Principles of Corporate Governance". The structure that brought its application was formed as follows:

I. Ensuring an effective framework for corporate governance.

II. The rights and obligations of shareholders as owners of the company.

III. The role of institutional investors, stock markets and their intermediaries.

IV. The role of stakeholders in corporate governance.

V. Corporate transparency.

VI. The responsibilities of the Board of Directors. 


\section{The Role of Corporate Governance Principles}

The OECD's first recommendation of 2004 (principle I) defined corporate governance as the means of promoting market transparency and fairness through the laws and, to this end, requires an adequate articulation of the duties of the state entities in charge of regulating and supervising markets. According to this criterion for the OECD, the principles of corporate governance should be included in the mercantile legislation of each country, be part of the jurisprudence of judicial bodies, be constituted as habitual practices of companies, so that the respective sanctions for non-compliance are also established ${ }^{5}$.

This criterion was in line with Principle VI-c, which required every member of the Board of Directors to create and apply high ethical standards in their organization to support the interests of stakeholders. In this regard, the OECD recommended that countries implement the fulfillment of such obligations to companies through the enactment of standards that enable their materialization ${ }^{6}$ and the work of their supervisory bodies.

The 2015 recommendations feature an interesting addition. It maintains the role of corporate governance as an instrument that generates "transparency" and "efficiency" in the markets but emphasizes that its promotional work should prioritize the "transparency" and "fairness" of the markets and the efficient distribution of resources generated by its activity, with the support of the law, the supervision of state regulators and compliance with its principles. In this case, the new criterion guiding the first OECD recommendation highlights two important aspects. The first aspect proposes that corporate governance should regulate the correct distribution of resources generated by the market. This is because the international organization considers that it is not enough to require markets to behave transparently and fairly, but that the distribution of their resources (profits) should be done with the same parameters.

The second aspect recommends that the legal systems and the regulatory and supervisory bodies of any country should not only verify the correct functioning of the market but should also examine the processes of distribution of resources in order to prevent potential abuses or excesses that could harm the interests of the weakest agents (depositors and other stake-holders).

\section{The Rights and Duties of Shareholder-investors}

The 2004 OECD recommendation, in principle II, stated that corporate governance should promote shareholders' rights while promoting equitable treatment in favor of shareholders as investors. The 2015 recommendations feature a new scheme by grouping both arguments together in principle II.

Also, the OECD recommendations explicitly promote investor activism and the control of conflicts of interest. In the first of the recommendations, the purpose of corporate governance is to create behavioral guidelines to promote the active participation of the investor in the governance of the company. In this regard, the OECD assumes the criterion that constant participation in the governance of a company increases its levels of transparency and those in charge of its management. The "activism" of the investor is a source of promotion of the activity of the company and; indirectly, allows to safeguard the economic interests of the investors and of the rest of the stakeholders.

Controlling conflicts of interest is another interesting aspect proposed by the OECD in its recent recommendations. Corporate governance rules must protect the interests of shareholder-investors and the interests of the company in those commercial transactions that the directors carry out with other companies with whom they have some type of relationship, such as belonging to the same corporate group. In this regard, the recommendations state that it is the obligation of the company and its directors to report the existence of conflicts of interest that may harm the interests of investors. Through the reporting of conflicts of interest as a guideline for corporate governance, a culture of transparency is fostered in companies and the promotion of efficient governance.

\section{The Role of Stakeholders}

In this section, the 2015 OECD recommendations (principle IV) repeat the guidelines provided in 2004. In these guidelines, the Organization issued a document on the principles of corporate governance, in which it develops the problems of the stakeholder and the function of the board of directors ${ }^{7}$. Regarding the former, the principles of corporate governance recommend compliance with regulations 
and the agreements reached with the various stakeholders linked to the company. Thus, it is sought to promote greater participation of employees in the governance of the company and the creation and implementation of an appropriate channel of communication with management. In this sense, the international organization advises the implementation of a protection framework in relation to bankruptcy proceedings ${ }^{8}$.

In this regard, principle IV is related to principle VI which establishes the obligation of the board of directors to implement "high ethical standards taking into account the interests of stakeholders"". Thus, the OECD subordinates its supervisory work not only to the interests of shareholders but extends it to other social segments related to the company's business: employees, creditors, customers, suppliers and local communities ${ }^{10}$.

The role of the boards of directors is to protect the interests of shareholders and stakeholders. In this way, markets will gain confidence that their interests are and will be permanently protected by the company. Therefore, supervision is not only a task of protection, but the constant work of transmitting confidence to the markets, of making them sharers in the profits that the company can offer them. To ensure this, any stakeholder can report and even sue board members in court for breach of their duties ${ }^{11}$.

For this reason, the OECD ${ }^{12}$ suggests that the selection of board members should consider not only their academic and professional profile, but also their behavior. The constant decision-making process regarding the destination of customer (in the case of financial companies) and investor deposits requires people with an ethical background capable of reconciling the needs of the company with those of shareholders and other stakeholders. Periodic evaluations should determine the personal and professional preparation of aspiring counselors, in which the personal aspect should be of vital importance.

\section{Transparency and Disclosure Policies}

The recommendations published by the OECD in 2015 are the same as those of 2004, albeit with minor changes. First, the recommendations require companies to report the non-financial information they possess as part of the exercise of corporate ethics and corporate social responsibility. In this respect, the OECD recommendations seek greater transparency in the exercise of the company's economic activity as well as better organizational and economic development.

Likewise, transparency guidelines propose that companies disclose the names of potential beneficiaries of company profits and conflicts of interest within the company. The aim of corporate governance is to promote the creation of its own self-regulation rules that generate the transparency of the company without neglecting the economic efficiency of its activity.

\section{The Task of the Governance Bodies}

According to OECD recommendations in 2004, the board of directors must be able to do its job. An organization improves its economic performance if it implements and complies with its business policies, such as protecting shareholders' rights, fulfilling contracts with suppliers, reporting information about the company and, chiefly, supervising the performance of the board of directors ${ }^{13}$. This OECD perspective demonstrates the importance of protecting stakeholders' objectives, including the employee as a vital part of the company and prioritizes the supervision of the company's actions in accordance with the interests of the corporation ${ }^{14}$. As for the 2015 recommendations, they call for two new obligations for boards. The first obligation requires them to implement legal mechanisms to facilitate access to the company's internal information to its members, especially its labor representatives, and thus improve their work. The second obligation is for boards to set up specialized committees, such as support bodies, to improve their role in complex matters such as auditing, risk management and executive remuneration.

The OECD considers boards of directors as the means to ensure transparency and supervision of the corporation's work and thus ensure the confidence of new investors, promote their growth and prevent any undue profit by senior management (CEO). ${ }^{15}$ 


\section{THE OECD RECOMMENDATIONS AND THE PROPOSALS OF THE CODE OF GOOD CORPORATE GOVERNANCE FOR PERUVIAN CORPORATIONS (2013)}

\section{The Role of Corporate Governance Principles (Principle I)}

In this regard, the Code states in its introduction that the role of corporate governance focuses on promoting the rights of shareholders and investors, generating value, soundness, efficiency in companies, improving risk management, access to the capital market, reducing the cost of capital, access to better sources of financing and other advantages (Code 2013: 4).

Also, the Code emphasizes the role of corporate governance as a means of promoting market efficiency but does not mention the distribution of resources generated by companies, the responsibility of state regulatory and supervisory bodies, or the need to include them in legal systems. In this case the OECD criterion should be included to improve transparency in profit-sharing processes in order to prevent future frauds that may harm market interests.

\section{The Rights and Duties of Shareholder-investors (Principles II and III)}

The 2015 OECD proposals aim to encourage greater investor participation in corporate governance and recommend that clear mechanisms of "active investor promotion" and "control of conflicts of interest" be implemented. In this case, the Peruvian Code assumes a passive criterion by limiting itself to listing the rights of shareholders and the obligations of companies towards them but does not propose specific acts that promote a greater interest in participating in the governance of the company.

A different situation is found in Principle 22 of the Code, which recommends the implementation of a series of specific duties on directors and managers to report any conflicts of interest that may exist in the company and imposes on them the duty to abstain from performing their tasks. These contributions, along with the creation of an ethical code to self-regulate the behaviors of its directors, are a great advance that the Code has implemented for the Peruvian market. Thus, the inclusion of new, specific behaviors could be the next step.

\section{The Role of Institutional Investors, Financial Markets and Other Intermediaries (Principle III)}

Given the importance that institutional investors have gained in the global market, the recent recommendations of the 2015 OECD dedicate a special section to recommend the implementation of mechanisms with the objective of preventing potential harm to their clients (beneficiaries). In this respect, the Peruvian Code is silent, and this is a serious concern when considering the criticism of the work of the Pension Fund Administrators, one of the major institutional investors in the country. This situation suggests the need for the Code to embrace OECD's recommendations and to implement a chapter dedicated to encouraging investors to comply with certain conducts to ensure the transparency of their work and the defense of the interests of their beneficiaries.

An interesting point to highlight is the recommendation that institutional investors contract the services of intermediation agents as part of their corporate governance practices. Although beyond the scope of this paper, the role of gatekeepers in other regions is noteworthy, promoting market transparency and empowering investor decisions in the market. However, the same comparative experience shows that brokers should not incur potential conflicts of interest with investors that could impair the transparency of their work.

\section{The Role of Stakeholders (Principle IV)}

Consideration of stakeholder interests is an important aspect that the OECD recommended in 2004 and repeats in 2015. The Peruvian Code does not develop this subject with the breadth and clarity that its importance has today. Principle 28 establishes as an obligation of the board of directors the implementation of an information policy for shareholders, investors, interest groups and the market in general. From then on, the Code omits to recommend aspects such as the recognition of the rights of the stakeholders with whom the corporation relates, and the promotion of active collaboration between corporations and stakeholders in the creation of well-being, jobs and the promotion of sustainability. 
In this sense, the Code omits to develop the problems of stakeholders from its recommendations because it prioritizes the attention to the interests of shareholders and ignores other stakeholders. Also, the Peruvian Code assumes the criterion of letting each company establish its own policies of attention and relationship with its interested parties in a discretionary fashion,

If either or both criteria are true, the Code makes a serious mistake. First, modern corporate governance promotes corporate transparency by involving all stakeholders and including their interests in decision-making. It should be stressed that corporate governance forms part of corporate social responsibility and its work should include specific actions that promote social responsibility in favor of the stakeholder more actively and binds to concrete actions that benefit the interests of the company and society. Therefore, the Peruvian Code should promote the exercise of a corporate governance of inclusion of the interests of all interest groups that have some link with the company.

\section{Transparency and Disclosure Policies (Principle V)}

The Peruvian Code develops the criterion of transparency of information in Principle 22 and in Pillars IV and $\mathrm{V}$ according to the recommendations of the OECD in 2004. However, the Code does not recommend the promotion of non-financial reporting and the enforcement of corporate ethics and responsibility. As well as the concern for stakeholders, it is likely that the criterion of the proponents of the Code was to leave it to the discretion of corporations to determine their ethical practices and corporate social responsibility. In this matter, the Peruvian Code should incorporate a set of recommendations for companies to improve their ethical and corporate responsibility practices.

Likewise, although it is already common for many companies to disclose the names of their shareholders, it is advisable for the Peruvian Code to recommend that companies report the names of the beneficiaries of their profits.

\section{The Task of the Governance Bodies (Principle VI)}

Properly, the Code develops the rights of shareholders and the work to be carried out by the governance bodies of companies (Shareholders' general meeting, board of directors and senior management). The role of the board of directors deserves special mention. The 2015 OECD recommendations on the incorporation of special committees and the implementation of an information policy are already included in principles 21 and 28, thus addressing one of the international organization's concerns about corporate governance.

An aspect that has been commented on in the section dedicated to Principle III and that deserves to be highlighted is the inclusion of the figure of the financial intermediary. An interesting innovation that should be included in the Code is the obligation for all intermediaries to publicly report any irregularity in the companies for which they work or in any other market agent. In this way, corporate governance practices will become more transparent and more reliable for the whole market.

\section{CONCLUSION}

This paper compared in a summarized way the recent recommendations published by the OECD in 2015 and compared them with the Good Corporate Governance Code for Peruvian Companies of 2013. The Peruvian Code requires the incorporation of various aspects that the international organization considers appropriate to prevent future financial crises and promote shareholder activism. First, the implementation of transparency mechanisms in the distribution of profits generated by financial markets is essential to prevent financial fraud that harms the interests of investors or of society itself.

The role of promoting shareholder activism is a pending task that the Peruvian Code should include in its recommendations. It should also be recommended the inclusion of concrete lines of action that promote greater interest and concern of investors to participate in the governance of the societies in which they have a stake. In this way, the risks of opportunism on the part of managers will tend to be significantly reduced. In this line of reasoning, the inclusion of a section dedicated to regulating the functions and duties of the institutional investor is essential because it will allow its activity to be limited 
to demonstrating that its acts of government are in the interests of its beneficiaries (clients). The role of stakeholders also raises greater concern in the business sphere and the Code should include more recommendations for companies to improve their transparency criteria and improve their corporate reputation. Finally, the role of the governance bodies should be confined to the fulfilment of their duties in favor of investors and other interest groups.

In summary, this paper proposes that the Peruvian Code should be adapted to the recent changes made by the OECD to improve the level of its recommendations that reduce a company's "bad" governance and benefit all its members: investors, employees, directors, creditors, government, and all the interest groups that depend on it.

\section{ACKNOWLEDGEMENT}

A Spanish version of this chapter of book was published in Estudios de Derecho Societario en Homenaje al Doctor Oswaldo Hundskopf Exebio, Ed. GES, Edit. Gaceta Juridica, Lima, 2017.

\section{ENDNOTES}

1. Hereinafter referred to as the Code.

2. Known as OECD.

3. Hereinafter referred to as the Code.

4. Oman, C.; Fries, S. and Buiter, W. (2003), pp. 6-7

5. OECD (2007), p. 107.

6. OECD (2007), pp. 110-111.

7. OECD (2004), pp. 17-66.

8. OECD (2004), p. 21.

9. "C. The board should apply high levels of ethical standards, considering the interests of stakeholders". OECD (2004), p. 24.

10. OECD (2004), p. 58.

11. OECD (2004), p. 59.

12. OECD (2009), p. 45.

13. Oman, C. (2001), pp. 12-13.

14. Oman, C. (2001), pp. 12-13.

15. OECD (1998), p. 24.

\section{REFERENCES}

Código de Buen Gobierno Corporativo para las Sociedades Peruanas: Contenidos y Alcances.

OECD. (1998). Corporate Governance: Improving Competitiveness and Access to Capital in Global Markets. OECD Publishing, Paris.

OECD. (2004). Principles of Corporate Governance. OECD Publishing, Paris.

OECD. (2007). Methodology for Assessing the Implementation of the OECD Principles of Corporate Governance. OECD Publishing, Paris.

OECD. (2009). Corporate Governance and the Financial Crisis: Key Findings and Main Messages. OECD Publishing, Paris.

OECD. (2015). G20/OECD Principles of Corporate Governance. OECD Publishing, Paris.

OECD Steering Group on Corporate Governance. (2010). Paper Corporate Governance and the

Financial Crisis. Conclusions and Emerging Good Practices to Enhance Implementation of the

Principles. OECD, Paris.

Oman, C. P. (2001)/ Corporate Governance and National Development. OECD Development Centre, Working Paper. 180, 1-45.

Tabra, E. (2015). Solidaridad y gobierno corporativo. Barcelona: JM Bosch. 